\title{
THE NOVICE ENGLISH TEACHERS' PERSPECTIVES TOWARDS ONE-PAGE LESSON PLAN PRINCIPLES AT SMP LABORATORIUM UNDIKSHA SINGARAJA
}

\author{
Ni Luh Ayu Novitasari ${ }^{1}$, I.G.A. Lokita Purnamika ${ }^{2}$, \& Putu Eka Dambayana Suputra ${ }^{3}$ \\ ${ }^{1}$ Universitas Pendidikan Ganesha \\ ${ }^{2}$ Universitas Pendidikan Ganesha \\ ${ }^{3}$ Universitas Pendidikan Ganesha \\ ayunovitasari147@gmail.com¹, lokitapurnamika@undiksha.ac.id ${ }^{2}$, eka.dambayana@undiksha.ac.id ${ }^{3}$
}

\begin{abstract}
The purpose of this study is to analyze the novice English teachers' perspectives on the one-page lesson plan principles at SMP Laboratorium Undiksha Singaraja. A case study qualitative design was used in this study. This study's data collection method included in-depth interviews to understand the novice teachers' perspectives. The subjects were two novice English teachers at SMP Laboratorium Undiksha Singaraja. The result showed the novice English teachers agreed one-page lesson plan is more efficient, effective, and students' oriented. However, novice English teachers had different perspectives for gathering students' information about the students' readiness, interests, and needs. This study implies that this one-page lesson plan policy needs to be sustained due to the English teachers' positive response.
\end{abstract}

Keywords: Novice teachers; One-page lesson plan; Perspectives.

\begin{abstract}
Penelitian ini bertujuan untuk menganalisis perspektif dari guru bahasa Inggris baru mengenai prinsip - prinsip RPP satu halaman di SMP Laboratorium Undiksha Singaraja. Penelitian ini menggunakan metode penelitian studi kasus kualitatif. Metode pengumpulan data yang digunakan pada penelitian ini menggunakan interview mendalam untuk memahami perspektif para guru baru bahasa Inggris lebih mendalam. Subjek penelitian ini menggunakan dua guru bahasa Inggris baru di SMP Laboratorium Undiksha Singaraja. Hasil dari penelitian ini menunjukkan bahwa para guru bahasa Inggris baru setuju bahwa RPP satu halaman lebih efisien, efektif dan berorientasi pada siswa. Walaupun demikian, para guru bahasa Inggris baru tersebut memiliki perbedaan perspektif didalam mengumpulkan informasi mengenai kesiapan, ketertarikan, dan kebutuhan belajar siswa mereka. Implikasi dari penelitian ini menunjukkan bahwa peraturan RPP satu halaman harus tetap digunakan secara berkelanjutan karena respon positif dari para guru bahasa Inggris baru tersebut.
\end{abstract}

Kata kunci: Guru baru; Perspektif; RPP satu halaman.

\section{INTRODUCTION}

A lesson plan is teachers' endeavor to consider the essential elements of students' need in learning, such as the learning objective, the instruction for students to understand the material, and the quantity of the information given to students (Johnson, 2000). Lesson planning is an essential aspect of teaching that needs to be prepared before the lesson to help teachers deliver the subject's material more effectively, efficiently, and organized-designing the lesson plan before the teaching and learning process can help teachers to visualize their learning process in 
the classroom (Haynes, 2010). Besides, designing the lesson plan and preparing the lesson before teaching is considered more effective for teaching and learning (Boikhutso, 2010). İn conclusion, a lesson plan is teachers' effort for designing guidelines for an effective, efficient, and organized learning process.

A lesson plan is not merely an activity guideline for teaching a topic, but there are more advantages than teaching without lesson planning. According to Boikhutso (2010), a lesson plan is essential to make pre - teachers improve their teaching competencies. Furthermore, a valuable lesson plan also contributes to the effectiveness of the communication on instructing teaching and learning process, which cause students' comprehension towards the material to increase rapidly. According to Raval (2013), a lesson plan is essential for teachers to design because it can make the lesson more effective and increase teachers' self-efficacy and evaluation. A recent study by Kapici \& Akcay (2020) mentioned that pre-service teachers' technology and pedagogical selfefficacy could increase after designing a particular lesson plan. However, designing a lesson plan is essential because it can improve teachers' pedagogical competencies, self-confidence, and effectiveness.

A lesson plan also has other advantages impacting students' learning process. For example, a lesson plan is the most effective way of dealing with prejudice, discrimination, and racism; by designing students centered lesson plan, students work cooperatively with heterogeneous groups (Moore, 2006). Furthermore, Vdovina \& Gaibisso's (2013) study reveals that a lesson plan can increase students' critical thinking by including a particular lesson plan model. Finally, a lesson plan can meet students' needs by using the students' assessment data in the previous lesson to consider the students' learning needs for the future lesson (Vdovina \& Gaibisso, 2013). Hence, a lesson plan is essential for students because it leads students to work cooperatively, increase their critical thinking, and fulfill their learning needs.

In Indonesia, the lesson plan has 13 components written under Culture and Education Minister No. 22 in 2016 about the standard of elementary and high schools' education process. The previous lesson plan components were school identity, subject, class/semester, material topic, time allotment, basic competency, indicators, learning objectives, learning method, learning media, learning resources, learning activities, learning material, and assessment (Kemdikbud, 2016). Therefore, the previous lesson plan should include all of the components written in the regulation. Whereas, based on the circular letter No. 14 in 2019 about the lesson planning simplification, only the main components are essential to be included (Kemdikbud, 2019). Therefore, the 13 components were divided into two categories; main and additional components (Kemdikbud, 2019). The main components are learning objectives, learning steps, and assessment. Meanwhile, the other components are additional components. Hence, Teachers needed more time to design the previous lesson plan.

The previous lesson plan using curriculum 2013 was determined to be a complex lesson plan. There is numerous research on teachers' difficulties while designing the lesson plan (see Gunawan, 2017; Palobo et al., 2018; Saputri, 2017; Sari, 2017). Moreover, a study conducted by Gani et al. (2017) reveals that teachers found designing the previous lesson plan using curriculum 2013 more challenging to prepare than the KTSP curriculum in developing the authentic assessment and formulating the indicator. Besides that, teachers lack teaching training about creating the lesson plan based on curriculum 2013. Furthermore, the previous lesson plan is written in detail because it contained 13 components. Therefore, İt can be seen that the previous lesson plan is considered a complex and detailed lesson plan, making teachers more focused on designing the lesson plan than the learning process.

The previous lesson planning format was recently changed into a one-page lesson plan format under Circular letter No. 14 about simplifying lesson planning in 2019. The components of a one-page lesson plan are divided into main and additional components. The main components include learning objectives, learning activities, assessments, and additional components (Kemdikbud, 2019). Based on the Circular letter, the one-page lesson plan is expected to make 
teachers work effectively by having more time on students' learning development instead of only focusing on designing a lesson plan. A one-page lesson plan has three principles written in the Circular letter; efficient, effective, and student-oriented. The one-page lesson plan principles are explained in the lesson planning pocketbook by Iskandar (2020). The efficient principle means designing a one-page lesson plan is effortless and time-saving. The effective principle means learning objective should be achieved. The students oriented means that a one-page lesson should be designed by considering students' readiness, interest, and needs. Therefore, teachers' effectiveness in designing lesson planning is concerned; hence, the previous lesson plan format was changed.

The changes of the lesson plan format were based on the government's perspectives for teachers' effectiveness. However, teachers' perspectives are also critical as the teachers design them. Teachers' perspectives are based on the cognitive process, impacting their teaching practice (Goodman, 1988). Moreover, according to Hall \& Smith (2006), teachers' perspectives are divided into three sections: planning, instruction, and reflection. Moreover, according to Hall \& Smith (2006), planning is crucial because it connects the teacher's pedagogical competency, curriculum, instruction, and students' learning process. However, teachers' perspectives and planning can be varied depending on several factors, and one of them is years of teaching experience.

Hall \& Smith (2006) highlight teachers' distinction due to their teaching experience in their teaching practice. Teaching experience differentiates between experienced and novice teachers, which may impact their teaching practice. According to Ünal \& Ünal (2012), teachers are categorized into novice teachers for those who have been teaching only less than seven years. Novice teachers are still developing their teaching and coping with their teaching practice (Çakmak et al., 2019; Sasson et al., 2020). Moreover, the lesson plan format changes in Indonesia might be challenging to cope with for the novice teachers; hence, the novice teachers' perspectives are chosen to be identified in this study.

Various studies have been conducted about the previous lesson plan, mainly about the difficulties of implementing the curriculum into the previous lesson plan (see. Madkur, 2013; Palobo et al., 2018; Saputri, 2017). Moreover, studies on teachers' perspectives on various education aspects also have been conducted (Hall \& Smith, 2006; Puspitasari et al., 2020; Rachmat, 2015; Shewark et al., 2018; Suryani et al., 2020). However, the novice English teachers' perspectives' on the changes of lesson planning format in Indonesia have been given a little attention.

Furthermore, the novice English teachers' perspectives were analyzed based on the one-page lesson plan principles in this study. The one-page lesson plan principles are efficient, effective, and students' oriented. Hence, this study identified the novice teachers' perspectives on the efficiency, effectiveness, and students' orientation of the one-page lesson plan. The novice English teachers' perspectives give a vivid picture of how the novice English teachers thought about education changes. This study's novice English teachers were chosen at a junior high school that met this study's criteria.

There are two novice English teachers at SMP Laboratorium Undiksha Singaraja implementing the one-page lesson plan. This school was chosen based on the criteria of the novice teachers in this study. The novice teachers at this school have been taught for less than seven years. The novice English teachers' one-page lesson plan at SMP Laboratorium Undiksha has been implemented and matched with Circular letter No. 14 about simplifying lesson planning in 2019. Although, all of the novice English teachers have been implementing the one-page lesson plan. İt is essential for getting a better understanding of their perspectives towards a one-page lesson plan. The novice English teachers at SMP Laboratorium Undiksha have been implementing the one-page lesson plan; hence, their perspectives on the one-page lesson plan are essential for better education in the future. 


\section{METHODS}

The qualitative approach is chosen by using a case study design in this study. This research method was chosen for identifying the novice English teachers' perspective at Smp Laboratorium Undiksha Singaraja. The setting of this study took place at Smp Laboratorium Undiksha because the novice teachers met the criteria of the study. The criteria are teaching under seven years (Ünal \& Ünal, 2012). Moreover, they also have implemented the one-page lesson plan using curriculum 2013. The subjects of this study were coded into N.E.T 1 (Novice English Teacher 1) and N.E.T.2 (Novice English Teacher 2). The study subjects, N.E.T 1, has been teaching for four years, and N.E.T 2 has been teaching for two and half years.

The data of this study were collected by using in-depth interviews. The in-depth interview questions were developed based on the principles of the one-page lesson plan. The one-page lesson plan principles are efficient, effective, and students' oriented (Kemdikbud, 2019). According to Iskandar (2020), the efficient principle of a one-page lesson plan means designing a one-page lesson plan is effortless and time-saving. The effective principle means that a onepage lesson plan should make students achieve the learning objectives. Thus, the studentsoriented principle is based on three indicators that teachers need to consider: students' readiness, interest, and needs.

The data analysis of this study used the model of Miles \& Huberman (1994). The data analysis model of Miles \& Huberman (1994) contains four stages; data collection, data reduction, data display, and concluding. The data collection stage was the stage when the data were collected. Thus, the data reduction stage is to determine the data. The Data display analyzed the data more in-depth to find and simplify the received data pattern. Drawing/verifying conclusion is the last phase representing the data pattern that is already being analyzed in the data reduction and data display. The data results checked the validity and reliability by using investigator triangulation and theory triangulation (Heale \& Forbes, 2013; Mathison, 1988). The investigator triangulation is used by having more than one investigator in this study. Moreover, the result of the result is matched with the previous related study in the data triangulation.

\section{RESULTS AND DISCUSSION}

The result of the in-depth interview with the English novice teachers at the Smp Laboratorium Undiksha is described into three parts. The three parts are based on a one-page lesson plan's principles; efficient, effective, and students' oriented. The result of the interview with the novice English teachers was quoted in each excerpt. Both novice teachers have similarities and differences in their perspectives toward the one-page lesson plan principles; efficiency, effectiveness, and students' orientation.

Firstly, based on the one-page lesson plan's efficient principle, both novice English teachers agreed that this one-page lesson plan is more efficient than the previous lesson plan. According to both novice teachers, this one-page lesson plan does not need much time to compare to the previous one. Both novice English teachers told the different times needed for designing the onepage lesson plan compared to designing the previous lesson plan. The following excerpt 1 shows N.E.T 1 how much time this novice teacher spent designing the previous lesson plan and onepage lesson plan.

Excerpt 1

N.E.T.1:

"I needed around two until three days for designing the previous lesson planning."

"I need a day for designing a one-page lesson plan."

"I do not need more time because this lesson plan is simpler and does not need to put the learning material in the lesson plan." 
Compare to designing the one-page lesson plan, this teacher only needed a day to design it. According to this teacher, designing the previous lesson plan needed more time, around two until three days. Designing the previous lesson plan took longer for this teacher because of a component in the previous lesson plan component. This teacher also explained that a one-page lesson plan is more straightforward because there is no need to put the lesson plan's learning material. Based on this explanation, this novice teacher believed that this one-page lesson plan is more efficient because of omitting one component of the lesson plan; the learning media. The N.E.T.2 teacher also agreed that using the one-page lesson plan is more efficient. According to N.E.T 2, designing this one-page lesson plan does not need much time and effort. This novice English teacher only needed $2-3$ hours for designing the one-page lesson plan and a day for the previous lesson plan format. The difference amount of time needed is enormous compare to designing the previous lesson plan. This novice English teacher explained more on the one-page lesson plan efficiency in the following excerpt 2.

Excerpt 2

\section{N.E.T.2:}

"I needed around two until three hours for designing a one-page lesson plan" and "for the previous lesson planning, I needed about a day to design a good lesson planning."

"I think it is more efficient because using this one-page lesson plan does not need much paper, especially the components that I will use for teaching are only those three components in the classroom, and the rest components are only additional components."

This teacher also explained why it does not need much time to design a one-page lesson plan. This one-page lesson plan only included the essential components from the previous lesson plan based on this teacher's explanation. Hence, a one-page lesson plan does not need much time to compare to the previous one. Furthermore, N.E.T.2 believed that a one-page lesson plan is efficient because it does not need much paper, although the efficient principle of a one-page lesson plan means time-saving and effortless. In conclusion, both novice teachers agreed that this onepage lesson plan is more efficient than the previous one because a one-page lesson plan only covers the essential parts; hence this one-page lesson plan is needed less time to design.

Secondly, according to the effective principle one-page plan lesson plan is designed for achieving the learning objectives. The effective principle of a one-page lesson plan means that the lesson plan can achieve the learning objective (Iskandar, 2020). Based on the result of the interview, those two novice English teachers have a different explanation. According to the explanation of N.E.T.1 that there were no significant differences in the students' learning achievement when the teacher used the previous lesson plan. Meanwhile, N.E.T.2 had the opposite opinion on the effectiveness of a one-page lesson plan. The explanation of the N.E.T.1 is shown in the following excerpt.

Excerpt 3
N.E.T.1:
"I think it is just the same with the previous lesson plan."
"until now I do not find any difficulties for achieving the learning objectives"

Based on this novice English teacher's explanation, there is no difference in the student's learning achievement. This teacher confessed, achieving the learning objectives are still the same as the previous one. Moreover, this teacher also said there are no difficulties in determining the learning objective and achieving it. Therefore, this teacher agreed that the one-page lesson plan is effective and did not find any difficulties for the learning objective, although the students' achievement of the learning objectives remains the same. Meanwhile, N.E.T.2 had a different 
opinion about the effectiveness of the one-page lesson plan. According to this teacher, the learning objectives are achieved better because they have more time to develop the learning material/media. This teacher is assumed to manage the time better because using the time used for designing lesson plans is now used to develop the learning material and media. Besides that, this teacher also did not have any difficulties in determining the learning objectives. The following excerpt answers N.E.T.2 about the effectiveness of a one-page lesson plan.

Excerpt 4

N.E.T.2:

"I think the learning achievement is better because teachers can focus more on creating learning media/material for the students, which means that teachers have more time for creating learning media/material in this one-page lesson plan."

"No, it is because the teacher decides the learning objective that should be achieved, so that, teachers know how many learning objectives that should be arranged and achieved based on the time allotment that is given to a subject."

This N.E.T.2 believed that students could achieve the learning objective better by using this one-page lesson plan. This is because the teacher can have more time to develop the learning material/media for helping students achieve the learning objectives. Moreover, this novice teacher did not find any difficulties in determining the learning objectives for the lesson plan's topic. However, N.E.T.1 believed that the student's achievement of learning objectives is the same using this one-page lesson plan. Meanwhile, N.E.T.2 believed that students' learning achievement is better by using this one-page lesson plan. Both novice teachers also confessed that the effective principle had been implemented well in their classrooms during the interview. Therefore, it can be concluded that both novice English teachers positively responded that a one-page lesson plan is an effective lesson plan, although both teachers have different believes on the students' learning achievement.

Thirdly, the students oriented that underlies the one-page lesson plan principle, which designing the one-page lesson plan is based on considering the students' readiness, interests, and needs. Both novice English teachers considered their students' readiness, interest, and needs based on the interview result. They have a different way of knowing about their students' readiness, interests, and students oriented. N.E.T.1 considered students' readiness, interest, and needs as shown in the following excerpt.

Excerpt 5

N.E.T.1:

"The factors that I consider are the students' readiness and the supporting facilities."

"I normally do it by checking their previous scores and observing them during the lesson and also following the trend."

Based on the above explanation, this novice teacher considers the students' readiness by considering the supporting facilities students have for conducting online learning in this pandemic. The teacher also considered students' interests and needs by looking at their scores from the previous semester and observing them during the class. It can be seen that this novice English teacher has been implementing the students' oriented principle of a one-page lesson plan by considering the students' readiness, interests, and needs. However, N.E.T.2 had different thoughts of the students' oriented principles in the one-page lesson plan. N.E.T.2 had a different way of considering the students' readiness, interests, and needs. This novice teacher considered the readiness by considering the appropriate application for online learning. 


\section{Excerpt 6}

N.E.T.2:

"in online learning the readiness factors that I consider such as: what kind of application can be used for online meeting, what kind of application can be used for doing the worksheets, what application can be used for editing video (creating project task), what kind of application that students need to prepare for opening the material that the teacher gave."

"I determine the students' interest by doing interviews with the students using google meeting, such as what kind of quiz they like in the learning process. Quizizz is the dominant used application. Hence, I normally use that application because according to the students, using that application is more challenging and the design of the application is more attractive and the time of doing the exercise also included"

"I know the students' learning needs by interviewing google meet. One of the students' needs that they want to be able to speak English fluently. Based on that, I mostly give materials like dialogue and ask students to create project video, so that they can practice speaking in front of their camera and also in the google meeting during this pandemic time."

According to the above excerpt explanation, this novice English teacher considered the students' readiness, interests, and needs. This novice English teacher 1 considered the students' readiness by considering the appropriate application that the students can use. The way this teacher knowing the students' interest was by asking the students in an online meeting. Furthermore, for considering the students' needs and interviewing the students, mostly the students wanted to be fluent in English. Overall, those two novice English teachers had the same perspective that they have implemented students-oriented principles in their lesson plan; however, they have a different way of getting information about their students' readiness, interests, and needs.

Based on the interview result, both novice English teachers agreed that a one-page lesson plan is more efficient and effective. However, they did have a different perspective that, according to N.E.T.1, that one-page lesson plan does not significantly impact the students' achievement. Meanwhile, N.E.T.2 had a different opinion that teachers can have more time to develop learning material, increasing students' achievement. Moreover, both teachers also confessed that they had implemented the student-oriented principle for their one-page lesson plan, although they had a different way of gathering information about their students. For example, N.E.T.1 said that this teacher observed and looked at the students' scores of their previous semester. Meanwhile, N.E.T.2 did an interview online in advance with the students to get to know their readiness, interests, and needs.

Therefore, it can be concluded that both novice English teachers agreed one-page lesson plan is more efficient, effective, and students oriented than the previous lesson plan. However, their understanding of the term effective in one-page lesson plan principles and their different perspectives on gathering students' information for the students' oriented principle should be considered.

The in-depth interview with the two novice English teachers shows their perspective on the one-page lesson plan principles. The principles of the one-page lesson plan are efficient, effective, and students' oriented. Based on the result, both novice English teachers have positive responses towards the efficiency, effectiveness, and students' orientation of the one-page lesson plan. However, both novice English teachers also have contrast perspectives about the effectiveness and students oriented. N.E.T.1 agreed that a one-page lesson plan is more effective than the previous lesson plan. However, based on this teacher's explanation, there is no significant difference between the students' learning objectives achievement. 
Moreover, the other novice teacher had a different thought, using a one-page lesson plan is more effective, and a one-page lesson plan can also impact the students' achievement. Furthermore, both teachers also have different perspectives on gathering students' information about their readiness, interest, and needs. For example, N.E.T.1 believed that gathering students' information about their readiness, interests, and needs can be done using observation and identifying their score in the previous semester. İn contrast, the other novice English teacher had different techniques of gathering students' information by using an online interview at the beginning of the semester. However, both novice English teachers have been implementing the one-page lesson plan and agreed that a one-page lesson plan is more efficient, effective, and student-oriented than the previous lesson plan.

The finding shows that a one-page lesson plan is more straightforward to design than the previous one. This finding does not support Madkur, 2013; Palobo et al., 2018; Saputri, 2017 because these studies highlight the difficulties teachers faced when designing the previous lesson planning, which does not happen with the one-page lesson plan. Hence, this finding supports Circular letter No. 14 about simplifying lesson planning because this one-page lesson plan principles impact both novice English teachers' efficiency in designing the lesson plan. However, the one-page lesson plan's effectiveness is still questionable because both of the novice English teachers had different opinions about their students in achieving the learning objectives, although both agreed that one-page lesson planning is effective to use. This redundancy from N.E.T.1 leads to the novice teacher's questionable understanding of the onepage lesson plan's effective principle. It is also needed to be concerned due to this study's limitation, which is the sample's limitation.

Moreover, the finding supports the previous study by Goodman (1988) that the teachers' perspective can impact their teaching practice. İt is along with the finding of this study that both novice teachers have different beliefs on gathering students' information about their readiness, interest, and needs. Therefore, their perspectives impact their consideration for their teaching practice, leading to the differences in their teaching practice and students' outcomes. Furthermore, this is also related to the study of Hall \& Smith (2006) that designing lesson planning is the relation of the teachers' cognitive process, pedagogical competency, curriculum, instruction, reflection, and students' outcomes. Therefore, İt can be concluded that teachers' perspectives can also impact designing the lesson plan, which also happens to novice English teachers in this study.

\section{CONCLUSIONS}

This study aims to identify novice English teachers' perspectives toward the changes in the lesson planning format. According to the government, the changes in the lesson planning format are due to increasing the teachers' work efficiency. This one-page lesson plan format has three principles that should be fulfilled. The one-page lesson plan principles are efficient, effective, and students' oriented. The finding shows that both novice English teachers agreed that a onepage lesson plan is efficient, effective, and student-oriented. Although different perspectives of the effective and student-oriented principles were found, it does not change the fact that a onepage lesson plan is more effective and student-oriented compare to the previous lesson planning format.

Based on this study's findings, it is expected that every teacher starts to implement the onepage lesson plan based on the one-page lesson plan principles. Moreover, every teacher in Indonesia should understand more about the one-page lesson plan principle. Furthermore, the following research is expected to concern the sample limitation of this study to get a bigger picture of the novice English teachers' perspectives towards a one-page lesson plan. Besides that, further information about teachers' techniques on gathering information of the students and the relation with their teaching practice is highly recommended to continue this study on the one-page lesson plan. 


\section{REFERENCES}

Boikhutso, K. (2010). The theory into practice dilemma: Lesson planning challenges facing Botswana student-teachers. Improving Schools, 13(3), 205-220. https://doi.org/10.1177/1365480210385668

Çakmak, M., Gündüz, M., \& Emstad, A. B. (2019). Challenging moments of novice teachers: survival strategies developed through experiences. Cambridge Journal of Education, 49(2), 147-162. https://doi.org/10.1080/0305764X.2018.1476465

Goodman, J. (1988). CONSTRUCTING A PRACTICAL PHILOSOPHY OF TEACHING : A STUDY OF PRESERVICE TEACHERS' PROFESSIONAL PERSPECTIVES preparation. Teaching and Teacher Education, 4(2), 121-137.

Gunawan, I. (2017). Indonesian Curriculum 2013: Instructional Management, Obstacles Faced by Teachers in Implementation and the Way Forward. 128(Icet), 56-63. https://doi.org/10.2991/icet-17.2017.9

Hall, T. J., \& Smith, M. A. (2006). Teacher planning, instruction, and reflection: What we know about teacher cognitive processes. Quest, 58(4), 424-442. https://doi.org/10.1080/00336297.2006.10491892

Haynes, A. (2010). The Complete Guide to Lesson Planning and Preparation. Continuum International Publishing Group.

Heale, R., \& Forbes, D. (2013). Understanding triangulation in research. Evidence-Based Nursing, 16(4), 98. https://doi.org/10.1136/eb-2013-101494

Iskandar, H. (2020). Tanya Jawab Rencana Pelaksanaan Pembelajaran (RPP). Indonesian Education and Culture Minister.

Johnson, A. P. (2000). It's Time for Madeline Hunter to Go: A New Look at Lesson Plan Design. Action in Teacher Education, 22(1), 72-78. https://doi.org/10.1080/01626620.2000.10462994

Kapici, H. O., \& Akcay, H. (2020). Improving student teachers' TPACK self-efficacy through lesson planning practice in the virtual platform. Educational Studies, O0(00), 1-23. https://doi.org/10.1080/03055698.2020.1835610

Kemdikbud. (2016). Peraturan Menteri Pendidikan dan Kebudayaan Nomor 22 Tahun 2016.

Kemdikbud. (2019). Surat Edaran Nomor 14 Tahun 2019 Tentang Penyederhanaan Rencana Pelaksanaan Pembelajaran.

Könings, K. D., Brand-Gruwel, S., \& van Merriënboer, J. J. G. (2007). Teachers' perspectives on innovations: Implications for educational design. Teaching and Teacher Education, 23(6), 985-997. https://doi.org/10.1016/j.tate.2006.06.004

Madkur, A. (2013). TEACHERS' VOICES ON THE 2013 CURRICULUM FOR ENGLISH INSTRUCTIONAL ACTIVITIES Maulidia Rachmawati Nur. IJEE, 1(2), 120-134. https://doi.org/DOI: 10.15408/ijee.v1i2.1340

Mathison, S. (1988). Why Triangulate? Educational Researcher, 17(2), 13-17. https://doi.org/10.3102/0013189X017002013

Miles, M. B., \& Huberman, ;A Michael. (1994). An Expanded Sourcebook Qualitative Data Analysis. In Sage Publications (2nd ed.). SAGE Publication.

Moore, J. R. (2006). Shattering Stereotypes: A Lesson Plan for Improving Student Attitudes and Behavior toward Minority Groups. The Social Studies, 97(1), 35-39. https://doi.org/10.3200/tsss.97.1.35-39

Palobo, M., Sianturi, M., Marlissa, I., Purwanty, R., Dadi, O., \& Nur, A. S. (2018). Analysis of Teachers' Difficulties on Developing Curriculum 2013 Lesson Plans. Advances in Social Sciences, Education and Humanities Research, 226(Icss), 1319-1324. http://creativecommons.org/licenses/by-nc/4.0/

Puspitasari, E., Pratolo, B. W., \& Mahfiana, A. M. I. (2020). Teacher's Belief about the Implementation of Curriculum 2013 in English Language. Ethical Lingua: Journal of Language Teaching and Literature, 7(1), 101-111. https://doi.org/10.30605/25409190.171 
Rachmat, Y. F. (2015). Teachers' Perspective on the Implementation of the 2013 Curriculum in Teaching English [Universitas Muhammadiyah Surakarta]. http://eprints.ums.ac.id/38694/

Raval, D. K. (2013). Lesson Plan: The Blueprint of Teaching. Raval / International Journal for Research in Education, 2(2), 155-157. www.raijmr.com

Saputri, M. (2017). English Teachers' Difficulties in Designing Lesson Plan Based on 2013 Curriculum. The State Islamic Institue of Surakarta.

Sari, S. A. R. K. (2017). The Problem Faced by English Teacher in the Implementation of Curriculum 2013 of the First Grade Students at SMP N 1 Delanggu in 2016/2017 Academic Year. 1-95.

Sasson, I., Kalir, D., \& Malkinson, N. (2020). The role of pedagogical practices in novice teachers' work. European Journal of Educational Research, 9(2), 457-469. https://doi.org/10.12973/eu-jer.9.2.457

Shewark, E. A., Zinsser, K. M., \& Denham, S. A. (2018). Teachers' Perspectives on the Consequences of Managing Classroom Climate. Child and Youth Care Forum, 47(6), 787-802. https://doi.org/10.1007/s10566-018-9461-2

Suryani, L., Fitriani, S., \& Sopian, R. (2020). Teacher's Perspective and Problem Toward the Syllabus Content in Curriculum 2013. PROJECT (Professional Journal of English Education), 3(2), 244-251.

Ünal, Z., \& Ünal, A. (2012). The impact of years of teaching experience on the classroom management approaches of elementary school teachers. International Journal of Instruction, 5(2), 41-60. 